\title{
Cemaat Sosyolojisi: Bir Kavramın Tarihsel Serüveni
}

\author{
Sociology of Community: Historical Adventure of a Concept \\ Mustafa Günerigök ${ }^{\text {a* }}$ \\ ${ }^{a}$ Dr. Öğr. Üyesi, Muş Alparslan Üniversitesi, Fen- Edebiyat Fakültesi, Sosyoloji Bölümü, 49250, Muş/Türkiye. \\ ORCID:0000-0002-2592-9284
}

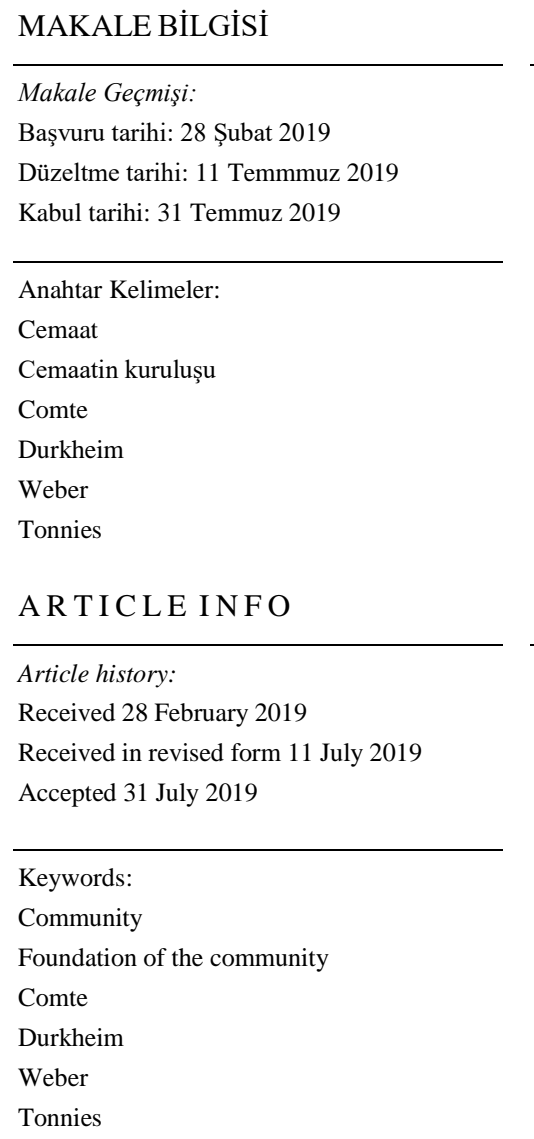

ÖZ

Cemaat olgusu, bir güven toplumu inşa etmeye dönük bir sosyolojidir. Cemaat kavramı ise günümüzde genellikle ortak ve refleksif bir kimlik ya da dünya görüşü duygusuna dayalı benzer ilgilere sahip özel olarak oluşturulmuş ve birbirleriyle sistematik bir etkileşim içinde olan insan gruplarını betimlemektedir. $\mathrm{Bu}$ bağlamda sosyologlar 19. yüzyıl rasyonalitesine dayalı cemaat tanımlarını aşmamız gerektiği iddiasını dillendirmektedir. Tarihsel süreçte bu kavram, toplum kavramı gibi çeşitli aşamalardan geçerek sosyolojinin temel paradigmalarından biri hâline gelmiş görünmektedir. Dolayısıyla cemaat konusu birçok açıdan araştırılması ve modern dönem sosyolojisinin gereklerine göre yeniden tanımlanması gerekir. Bu çalışmada, cemaat kavramının tanımı, sosyolojisi, klasik dönem sosyolojisinde nasıl anlaşıldığı ve özellikle sosyolojinin kurucularından Comte, Durkheim, Weber ve Tonnies'in bu konuya dair yaklaşımları genel bir perspektifle ele alınmıştır.

\begin{abstract}
A B S T R ACT
The fact of community is a sociology to build a community of trust. The concept of community, nowadays usually describes the groups of people who are in a systematic interaction with each other and specifically with similar interests based on a common and reflexive identity or sense of worldview. In this context, sociologists express the claim that we must transcend the definitions based on the rationality of the 19th century. In the historical process, this concept seems to have gained the identity as one of the basic paradigms of sociology through various stages such as the concept of society. Therefore, the issue of community should be investigated in many ways. In this study, definition of community concept, sociology, how it is understood in the sociology of classical period and especially the approaches of of the founders of sociology such as Comte, Durkheim, Weber and Tonnies, are discussed from a general perspective.
\end{abstract}

\section{Giriş}

Sosyoloji, temsil iddiasında olduğu çağı yakalayabilmek ve yorumlayabilmek için giderek daha sofistike alt disiplinlere bölündü. Bu süreç kanonik yapının temel kavramlarını da değişime uğrattı; temel kavramlar yeni içerikler kazanmaya, farklı disiplinlerle bakışımlı anlamlara temas etmeye başladı. Cemaat kavramı da bu akışın dışında değildir, o da bu uzun sürecin kendisine koşut uzun bir soykütüğüne sahiptir. Sosyolojinin yeni bir bilim olma iddiasıyla gün yüzüne çıktığı ilk zamanlardan günümüze gelinirken cemaat kavramı da kısa sayılmayacak bu süre içerisinde aktüel tartışmalarına matuf bir şekilde yeniden tanımlandı ve yeni içerikler kazandı. Dolayısıyla cemaat kavramı sosyoloji uygulamasında refleksif (düşünümsel) (Günerigök, 2015: 41), çok anlamlı, dolayısıyla son derece karmaşık ve muğlak/sofistike bir yapı olarak karşımıza çıkar.

Cemaat sosyolojisinin önemli savunucularından olan sosyolog Nisbet'e (2013: 65) göre sosyolojik düşünce

\footnotetext{
* Sorumlu yazar/Corresponding author

e-posta: m.gunerigok@alparslan.edu.tr
} 
geleneğinin kurucu fikirleri arasında yer alan beş temel paradigma arasindan en temel ve uzun soluklu olanı “cemaat”tir. Dolayısıyla 19. yüzyıl sosyoloji düşüncesinin tartışmasız en dikkate değer gelişmelerinden biri, cemaatin yeniden-keşfidir. Hatta bu olgu, sosyolojik teorinin ötesine taşarak 19. yüzyıldaki imajinatif literatürün ana temalarından biri hâline gelmiştir. Ayrıca bu vakı edebiyat, felsefe, tarih ve teoloji gibi alanlara uzanacak kadar geniş bir yelpaze üzerinde gelişme göstermiş ve bu disiplinleri de dönüştürmüştür. 19. yüzyılın sosyal düşüncesini önceki çağdan, yani aydınlanma çağından bu kadar belirgin olarak ayıran başka herhangi bir fikir düşünmek bir hayli zor görülmektedir. Denilebilir ki cemaatin keşfi aydınlanmadan sonraki uğrakta merkezde durmakta, dolayısıyla çağdaş sosyolojinin cemaat kavramıyla ilgili değerlendirmelerinde modern bilinç ve kavrayış gözardı edilemeyecek bir konum işgal etmektedir. Ancak bugünkü cemaat realitesinin paradigmal anlamda farklılaştığını, yeni içerikler kazandığını ve yaşanılan değişime bağlı olarak hala toplumsal mobilizasyonu sağlama noktasında oldukça etkin bir işleve sahip olduğunu (Çaha, Aktay vd. 2011: 23) da unutmamak gerekir ${ }^{1}$.

Sosyolojik kavramların oluşum süreci tarihî vakaların oluşumuna benzer. Art alanlarında birçok değişken vardır. $\mathrm{Bu}$ değişkenlerin bir toplamı olarak gün yüzüne çıkarlar. Fakat tarihî vakalar ile aralarında bir fark vardır, sosyolojik kavramlar bütün hâlinde duran sosyolojik bir teorinin içerisinde anlamlıdırlar. Sosyolojik teoriler, sosyolojik kavramları da kapsar ve onlara belirli bir mekân tayin ederler. Yanı sıra söz konusu teorilerin tasvir ve eleştirme iddiasında bulundukları tarihsel bir gerçeklik vardır. Dolayısıyla bir yönleriyle sosyolojik teorilere ilişik dururlarken bir yönleriyle de tarihsel gerçekliğe atıf yaparlar. Hem sosyolojik teorileri hem tarihsel gerçeklikleri birden göz önünde bulundurmak gerekir.

Özetle sosyolojik kavramlar tarihsel olarak ele alınmalı, kendilerini var kılan tarihin yörüngesinde okunmalıdır. Kavramların tarihsel anlamları dünyada vuku bulan olaylardan/zamandan ve bu olayların getirdiği bilinçten/uzamdan bağımsız değildir. Esasen sosyolojik teoriler de bu insanlık durumlarının bir yansıması şeklinde okunabilir. Hâl böyle iken kavramların tarihsel olmayan bir nazarla okunmaları, belirli bir oluşum çizgisini dikkate almadan değerlendirilmeleri onların anlamını saptırır ve mekânsızlaştırır. Dolayısıyla cemaat kavramı ve cemaat sosyolojisini de aynı kaygıyla ele almak, içlemini bu yöntemle açık kılmaya çalışmak en doğru yol olacaktır.

Cemaat kavramını yalnızca ulus devlet merkezli rasyonel düşünce üretiminde kazandığı anlamıyla değil, post-seküler ve post-modern muhayyileye yönelimli yeni açılımların 1şı̆̆ında da okumak gerekir. Daha doğrusu cemaat kavramı ve cemaat sosyolojisini ele alırken belirli bir dönemin vurgusunu ön plana çıkarmaktansa onları var kılan sürecin açımlanması ve ardından sosyolojik bilincin vardığı aktüel yeri hesaba katan yeni bir tanıma varmak gerekir. 1945'ten sonraki entelektüel ve siyâsi dönüşümün sosyolojik bilinci

\footnotetext{
${ }^{1}$ Cemaat kavramı ve sosyolojisinin geç modern dönem tanım ve işlevselliklerine daha sonra ele alacağımız bir çalışmada detaylı bir şekilde konu edineceğimiz için burada yer vermedik.
}

de dönüştürdüğü aşikarken sosyolojik bir kavram olan cemaatin bundan ârî kalacağını düşünmek doğru değildir. Neticede anahtar bir kavrama dair semantik analizin temel meselesi, o anahtar kavramın kavramsal bir anlam kazanma süreci olduğundan, anahtar kavramların hem tarihî-teorik hem de semantik temelleri üzerinde yoğunlaşmak gerekir (Davutoğlu, 2018: 46).

Bu çalışmada cemaat kavramının ve cemaat sosyolojisinin tarihsel gelişimini genel hatlarıyla açık kılmaya çalışacağız. Başka bir ifadeyle ana akım sosyolojinin oluşumunda merkezde bulunan Comte, Durkheim, Weber ve Tonnies benzeri isimlerin cemaat kavramı ve cemaat sosyolojisine dair çıkarsamalarını ve hükümlerini betimsel bir okumaya tâbi tutacağız. Postmodern ya da Ulrich Beck'in tanımlamasıyla ikinci modernite dönemi uzanımlarını dışarda bırakacak şekilde olası modern cemaat tanımları etrafında bir düşünüm gerçekleştireceğiz.

\section{Tarihsel Bir Derkenar}

Modern Batı düşüncesinde cemaatin kuruluş teorisi üzerine düşünenlerin ekseri, cemaat olgusunun politik ve sözleşmeye dayanan bağlarla kurulduğunu düşünür (Delanty, 2015: 15,16). Bat1 sosyoloji geleneğinde Ortaçağ'dan Reform ve Rönesans çağına ve bu ilerleme güzergâhında Comte'dan Weber'e kadar komünal olan ile komünal olmayan arasındaki karşıtlık canlı ve keskindir. Alman sosyolog Tonnies (2001) bu kavramsal karşıtlığa, 19. yüzyılın sonlarına doğru Gemeinschaft ve Gesellschaft dikotomisi ile uzun bir süre çözüm odaklı bir terminoloji kazandırır. Ancak burada görünen karşıtlık, ondan önceki ve diğer sosyologların hiçbirinin eserlerinde bu kadar bariz değildir. İki paradigma arasında ortaya çıkan mesafe radikal bir söyleme hatta kimilerine göre ideolojiye dönüşecektir. Bunun tek istisnası karşıtın taşıdığı değer yüklü sonuçlardan önemli ölçüde kaçınan Marx’tır (Nisbet, 2013: 66).

Tarihsel sürece bakıldığında Aristoteles'in toplumun doğası üzerine düşünceleri insanî birlik veya ortaklık/cemaat (community/koinonia) biçimlerinin analizi üzerinden, şehir devletinde yurttaşlar arasında gerçekleşen bir cemaat biçimi olan devletin analizine ulaşıldığı görünmektedir. $\mathrm{Bu}$ analizdeki birlik, cemaat ve toplum kavramları koinonia terimi altında toplanmıştır. Aristoteles toplum kavramı için ayrı bir kavram kullanmamıştır. Ayrıca onda cemaat ile toplum ve devlet ile toplum arasında bir sınır konmamıştır, bunlar arasında keskin ayrımlar olduğunu kabul eden modern bilincin aksine bunları birbirinden ayırmadan bir organizma şeklinde ele alır. Runciman'ın da belirttiği üzere Aristoteles'in yaptığı en önemli ayrım toplum ve devlet arasında değil, kişisel veya sosyolojide en temel cemaat biçimi kabul edilen ailevî olan ile siyasal-toplumsal arasındadır. Bununla beraber, siyasal olanın felsefesini geliştirme bağlamında, "yurttaş toplumu", "siyasal toplum" kavramını barındırdığı bir dizi ayrımı öne sürer (Derek, Frisby, 2013:16).

Ayrıca Aristoteles'in yaklaşımında komünal ve toplumsal olan arasında önemli bir fark yoktur. Çünkü toplum kültürel sermaye odaklı bir kavramdır. Antik Yunan şehir devleti polis, içeriğinde politik, sosyal ve ekonomik ilişskileri de 
barındirıyordu. Aristoteles aslında bu şehri bir cemaat (koinonia) olarak görüyordu. Ona göre, polis arkadya denen şehirlerde yer alan kabile ve kırsal kesim sosyal ilişkilerinin tersine, kentsel bir kimliğe sahipti. Yunan kentinin komünal yapıları, insanların sosyal kimliklerinin en üst düzeylere çıkartıldığı sözleşmeye dayalı bağlar oluşturmaktaydı. Bu nedenle, toplumun yükselişinden önce cemaatin altın çağ olan 19. yüzyılda yapılan romantik ve nostaljik ayrımın modernite öncesine yüklediği cemaat tanımı tartışmaya açık görünmekte ve dolayısıyla modern bilinç öncesinde böylesi ayrımlar kurmanın geriye dönük okumaların bir yanılsaması şeklinde durmaktadır.

Cemaat, Antik Yunanlardan Aydınlanma çağına kadar "toplum"un karşı savını değil temelini yansıtır. Modern dönemde ise Tonnies'in (2019) yorumları örneğinde görüleceği gibi tam tersi bir durum söz konusudur, cemaat ve toplum (cemiyet) bir gerginlik ekseninde karşı karşıya durmaya başlarlar. Hatta Tonnies'ten önce de cemaat kavramı Antik Yunan'daki anlamıyla kısmen farklılaşmış olsa da benzer bir anlam dünyasında ikamet etmeye devam eder. Örneğin Rousseau'ya göre, 18. yüzyıl modern sivil toplumu, bir yurttaşlar birliği olarak Yunan şehir devleti yapısına dayalıydı. Aydınlanma çağında cemaat kavramı yeni gelişmekte olan toplum dünyasını da kapsıyordu. Buna göre, kavramın müşterek/ortak tecrübeleri paylaşan ve ortak toplumsal bağları ifade edecek şekilde geniş bir bağlamı dolayımında kullanıldığını söyleyebiliriz. Yani cemaat kavramı bu dönem zarfinda devlet veya ev içindeki özel dünyaya dair bir yapıya indirgenmemiştir. Cemaat, kastedilen devirde toplumsal ilişki tanımını adeta otokrat devlet ile olan gerginliğin bir göstergesi olarak çok güçlü bir şekilde vurgulanmaktadır. Devletin aksine cemaat daha dolaysız olan bir gayeye ait olmaklıktan ve günlük yaşam dünyasından bahsediyordu. Başka bir ifadeyle devlet, kentli yurttaşların yaşamlarından oldukça uzak olan objektif ve mesafeli bir yapıyı tasvir ederken cemaat, doğrudan yaşanan ve tecrübe edilen bir aidiyeti belirtiyordu. Modern düşüncenin ilk dönemlerinde Aydınlanma öncesinin aksine cemaat ve toplum adeta birbirinin yerine kullanılıyor, bir oluşumun karşıt güçleri şeklinde tasvir edilmiyordu.Bu dönemde cemaat, "yaşam-dünyası"na, günlük hayatın deneyimlenen dünyası olan sosyal alana işaret ediyordu. $\mathrm{Bu}$ alanlar, gün geçtikçe daha fazla birbirinden ayrılsalar da 17. ve 18. yüzyillarda bu kavramlar toplum imgeleminde ve toplumu konu edinen teorilerde neredeyse aynı şeyi ifade ediyordu. Cemaat ve toplum kavramlarının bu şekilde birbirinin yerine kullanılması hem yaşanılan, idrâk edilen zamanların hem modern öncesi bilincin bir sonucudur. Modern bilinç öncesindeki toplum düşüncesi insan yaşamındaki çocukluk evresini andırır: henüz çevresi ve kendisi arasında bir ayrım gözetmemekte, kendi varlığını kendi bilincinde yeniden ve kendisi için kuramamaktadır.Durkheim'in de öne sürdüğü gibi19. yüzyılın sonlarına kadar toplumsal kavramının nevi şahsına münhasır bir tanımı dahi yoktur (Delanty, 2015: 16). Dolayısıyla toplum ve cemaat ayrımı modern zamanların bilincinde açı̆̆a çıkan fenomenlerdir.

Williams'a (2016: 354) göre toplum kavramı (society) İngilizceye 14. yüzyılda eski Fransızca yakınkök sociéeté, Latince societas 'tan, o da Latince kök sözcük socius 'tan arkadaş- geçmiştir. Toplum kavramı (society), 16. yüzyılın ortalarına kadar arkadaşlığın fiilîbirlikteliğine veya 1381 İngiltere'de Wat Tayler liderliğinde gerçekleşen ve literatüre "köylü devrimi" olarak geçen olayda olduğu gibi genel bir ilişki içerisinde birbirlerinin yardımına ihtiyaç duyan insanlar arasında gitgide büyüyen sevgi ve arkadaşlığa ve bu arkadaşlığa duyulan gereksinime ya da 1580'lerde daha basit bir arkadaşlığa işaret ederken 16. yüzyılın sonlarına doğru geniş bir anlam dünyasını tasvir etmeye başlar.

Toplumun bir terim olarak dolaşıma girmesi; Hobbes, Rousseau ve Vico'nun eserleriyle beraber ortaya çıkan sosyolojik düşünceden en az yüzyıl öncesine dayanmasına rağmen toplum fikri üzerine genel bir uzlaşı mevcut değildi. Neticede insan toplumunun nasıl oluştuğu ve yeniden nasıl üretildiği soruları Platon ve Aristoteles'in yabancısı olduğu sorular değildi. Fakat yine de söz konusu devirlerde toplumun kendisini merkezi bir konumda ve tarihin öznesi şeklinde ele alan bir düşünce ortaya çıkmadı. Bu meselenin Batı siyasi düşüncesi içerisinde, klasik dönemden günümüze uzanacak bir şekilde kök salmış olması, toplum kavramının neden bu denli başat bir tartışma alanı olarak süregeldiğinin anlaşılmasını zorlaştırmaktadır.

Toplum, süreç içerisinde politik ilişkilerin aksine ekonomik ilişkileri de kasteden yurttaşlık bağı olarak görülüyordu. Sivil toplum da ortak bağ ya da topluluk kapsamında ele alınabiliyordu. Dolayısıyla cemaat, söz konusu dönemde sadece gelenek ve anane gibi anlamlara gelmeyip genel olarak bütün sosyal ilişkileri ifade ediyordu (Delanty, 2015: 16, 17). Fakat "cemaat kavramı"nın kaderi tıpk1 "gelenek (tradition) kavramı"nda olduğu gibi dinî söylemi çağrıştırdığı iddiasıyla seküler entelektüel kültüre bilinçli bir şekilde taşınmaz. Onun yerine cemiyet/toplum kavramı bir söylem dâhilinde modern kültürde dolaşıma konulmuştur. Neticede gerek cemaat gerekse de cemiyet, toplumsal birer grup olsalar da; yine de bu iki yapı, farklı ilişkileri temsil eder (Wagner, 2019).

\section{Modern Dönem Cemaat Sosyolojisi}

Modern sosyolojinin önemli entelektüelleri arasında yer alan Saint Simon, Comte, Spencer, Le Play, Tocqueville, Durkheim, Weber, Marx, Tonnies ve Simmel benzeri toplum kuramciları "cemaati savunmak gerekir" sosyolojisine yakın durmuşlardır. Söz konusu isimlerin ütopik bir tasarım olarak da okunmaya müsait olan cemaat merkezli bir sosyolojileri vardır. Cemaat, bu sosyolojilerde merkezi bir yere geçer. Örneğin, Spencer, "askerî sına-i"; Comte, "muhafazakâr cemaat"; Durkheim, "etik/ahlâkî cemaat"; Le play, "empirik cemaat"; Marx, "sosyalizm"; Weber, "rasyonelleşme"; Tonnies, "Gemeinschaft ve Gesellschaft"; Simmel, "moleküller cemaati" (Nisbet, 2013) bu yaklaşımlardan öne çıkanlardan birkaçıdır. Bu sosyolojilerin içinde, Modern dönemde yaşanılan değişimin yorumlanması için Tonnies'in ortaya koyduğu tipoloji/sosyoloji çağın diğer tanımlamaları arasında güçlü bir şekilde yankılanmış ve birçok sosyolog tarafindan yeniden yorumlanmıştır.

\subsection{Comte ve Muhafazakâr Cemaat}

Auguste Comte (1798-1857)'un cemaate yönelik sosyolojik ilgisi yaşadığı dönemde geleneksel ilişki biçimlerinin 
çözülmesi ya da dağılmasından kaynaklanmaktadır. Comte'un zamanında toplum kendisini bir arada tutan ilke (krallık ve aristokrasi) ve inanç bağlarından (kilise) kopmuş ve belirsizliğe doğru olan bir değişim cenderesine sürüklenmiştir. İlişki biçimlerinin bu kökten değişimi Comte'un sosyolojisinin niyetini belirler. Onun sosyolojisi üzerinde geleneksel/muhafazakâr cemaatin hayaleti dolaşır ve bir liberal muhafazakâr cemaat kurma tutkusu, kurduğu sosyal piramidin her düzeyinde canlı bir şekilde niyetini açığa vurur. Ergenlik çağından itibaren ateist biri olsa da Katolik bir formasyondan geçmişti. $\mathrm{Bu}$ yüzden muhafazakârların düzen ve manevî birlik kaygısını paylaşmaktaydı. Yanı sıra Aydınlanmacı ve liberal öğretilerden de etkilenen Comte, eski düzene dönüşün mümkün olmadığını ve bu nedenle geleneksel dünyada var olan dinsel otoritenin işlevsel düzeyde dengi olabilecek bir cemaatin yaratılması gerektiğini savunur (Turner vd. 2010: 38). Comte'un cemaate yüklediği anlam, metaforik bir şekilde ifade edilirse, Ortaçağ şişelerine doldurulan pozitivist şaraptan başka bir şey değildir.

Comte'a göre, cemaatin restorasyonu ahlâkî bakımdan aciliyet kesbeden bir meseledir. O, bu bağlamda insanî olan her şeyi, tıpkı Durkheim gibi, toplumun bütünüyle fizyolojik türevi düzeyinin üzerine yerleştirir ve yine Durkheim gibi, bariz bir şekilde toplumu büyük bir cemaat olarak görür (Nisbet, 2013: 77-81) ve Aydınlanma felsefesinin bireyi merkeze alan popüler yaklaşımlarına karşı toplumu kutsal bir mabet gibi algılar. Zira onun için toplum, bağımsız ve önceliklidir; mantıkî psikolojik bireyi önceler. Kisacası, toplum bireyi inşa eder. Toplumdan bağımsız bir şekilde bir bireyin eylemleri algılanamaz.

Comte, toplumu pozitivist tapınmanın "Üstün Varl1k"1/“Tanrı"s1 yapar. Bu sosyolojinin temelinde birey ve birey olmaklik tamamen reddedilmiş ve bireyin araştırılmasını psikolojiye bırakmıştır. Toplum yalnızca toplumsallığın özünü paylaşan unsurlara, metafizik aklın inşa ettiği bireylere değil, yani sosyal gruplara ya da cemaatlere indirgenebilir. Bu unsurların en önemlisi hiç şüphesiz "aile"dir (Nisbet, 2013: 82). Aile, diğer tüm toplumsal birimlerin nihayetinde kendisinden geliştiği en temel sosyolojik birimdir. Comte, bu yüzden toplumsal yapıların bireylerin özelliklerine indirgenemeyeceğini savunan güçlü işlevsel sosyolojist bir yaklaşımı benimsemektedir. $\mathrm{Bu}$ sosyolojiye göre toplumsal yapılar başka yapılardan oluşur ve onlar sadece diğer yapıların özellikleri ve ilişkileri dikkate alınarak anlaşılabilir.

Comte'un aile analizi, onun cemaat yapısını açıklamaya yöneliktir. Comte, bu doğrultuda cinsiyete dayalı işbölümü ve ardından ebeveynlerin ilişkilerini açıklar. Aslında konumuz açısından bu analiz çok önemli değildir. Bizim için çok daha önemli olan bu sosyolojideki sosyolojik yapı anlayışıdır. Zira toplumsal yapılar çeşitli alt yapılardan oluşur ve daha basit yapılardan gelişirler (Turner vd., 2010: 46). Bu temel noktayı açıkladıktan sonra Comte, ilerlemeci bir kaygıyla, kaybedilen cemaati sosyal statikte, yeniden üretilecek olan cemaati ise sosyal dinamik sosyolojisinde bulmaya çalışacak (Comte, 2000: 230-249) ve nihaî hedef olarak tasarladığı "insanlık dini”" cemaati için Pozitivizm İlmihali'ni yazacaktır (Comte, 1986: L). Sonuç olarak Comte'un liberal muhafazakâr cemaat ruhu Durkheim sosyolojisi üzerinden sosyolojik muhayyilede varlığını sürdürecektir.

\subsection{Gemeinschaft versus Gesellschaft}

Modern cemaat sosyolojisinin kurucusu Alman sosyolog Ferdinand Tonnies (1855-1936)'tir. Üzerinde İbn Halduncu izler taşıyan Tonnies, Gemeinschaft (cemaat/topluluk) ve Gesellschaft (toplum/cemiyet) gibi dikotomik paradigmalarla Durkheim, Weber, Sombart ve Simmel gibi birçok kişiyi etkileyen bir sosyologdur. En bilinen eseri de Gemeinschaft und Gesellschaft'tır. Tonnies'in sosyoloji disiplinin gelişimine yön veren bu kitap ilkin 1887'de Almanca yayımlanmıştır. Eser Tonnies'in doktora çalışmasıdır. 1957 yılında Community And Society adıyla İngilizceye, 2019 y1lında Cemaat ve Cemiyet adıla Türkçeye çevrilmiştir.Bu çalışma geç modern döneme geçişi iki önemli kavram/toplumsal yapı üzerinden açıklayan ilk sistematik çalışmalardan biri olmuştur (Yelken, 1999: 33-53; 2012: 257).

Tonnies, Cemaat ve Cemiyet adli eserinde,cemaat ve toplumu karşı1t kutuplar şeklinde mütalaa eder: dayanışmacı nitelikler taşıyan ilişki biçimleri (cemaat) ile sanayileşen toplumların gayri şahsî ilişki biçimlerini (toplum) karşı karşıya getirerek toplumsal birliğin bu biçimlerine ilişkin ideal-tipik resimler çizmiştir. (Marshall, 1999: 90). Kavram olarak “cemaat", Gemeinschaft'in nüanslarını yansitıyor denilebilir. Ama Gesellschaft kavramının Türkçeye aktarılması daha zordur. Ancak Yelken'e (1999: 39) göre Gemeinschaft kavramı Türkçede "cemaat" veya "topluluk" olarak çevrilmesi uygundur. Yelken topluluk kavramının herhangi bir gurubu ifade etme riski nedeniyle cemaat kavramının tercih edilmesinin daha uygun olduğunu ifade etmektedir. Ayrıca Tonnies'in sosyolojisinde Gesellschaft'ın taşıdığı modern/kentsel anlamı yansıtabilmek için Türkçeye "cemiyet" olarak çevrilmiştir. Yelken cemiyet kavramının yerine "toplum" kavramının tercih edilmesinin daha iyi olacağını düşünmektedir. Nisbet'e göre de İngilizceye civil society şeklinde çevrilen Gesellschaft çevirisi (Tonnies, 2001) aslında salt society (toplum) olmalıdır.Kavramsal tartışmalara girmeden mevzuya baktığımızda Tonnies bize Avrupa toplumunun gelişiminin önce cemaat birliklerinden cemaat ilişkilerine, sonra toplum ilişkilerine; son olarak toplum birliklerine doğru gerçekleştiğini söyler. Tonnies'in çıkış noktası insan iradesinin farklı biçimleridir. Tonnies, ilkin başka insanların iradesini ya da bedenini yok etme eğiliminde olan iradeler ile bunları koruma eğiliminde olan iradeler arasında ayırım yapar. Tonnies'e göre cemaat ve cemiyet yapıları ancak olumlu ve teşvik edici yönler baskınsa varlık kazanabilirler (Wagner, 2019; Tonnies, 2019: 42-56). Olabildiğince refleksif görünen bu anlatı Tonnies'in tipolojikleştirdiği sosyolojinin bir özetidir (Nisbet, 2013: 102).

Tonnies'in geliştirdiği Gemeinschaft biriminin prototipi Comte da olduğu gibi “aile"dir. Bu cemaatin üç temel direği -kan, yer (toprak), akrabalık, komşuluk ve dostlukailede mevcuttur. Ancak ilk temel sütun ailedeki kurucu unsurdur. $\mathrm{Bu}$ bağlamda Gemeinschaft mükemmel bir dostluk, ortak bir işe ya da faaliyete ve inanca dayanan ruh ve zihin olarak yorumlanır. Gemeinschaft sosyolojisinin 
tezahürleri arasında loncalar, sanat ve zanaat arkadaşlıkları, kiliseler ve kutsal tarikatlar yer alır. Bütün alt organizasyonlarında aile fikri çok belirgindir. Gesellschaft ise Avrupa toplumunun modernleşme sürecini yansitan ve yabancılaşan bir süreç olarak algılanabilir. Gesellschaft'ın özü "rasyonalite" ve "hesapçılık"tır; mekânı ise kenttir. Tonnies'in yaklaşımında, cemaat ve cemiyetin pratik hayattaki fenomenlerde keskin bir karşıtlık, belirgin bir zıtlık içerdiğini söylemek bir hata olacaktır. Zira her bir kavramı, gelenek ve modernite şeklinde ayırmak mümkünse de, esas olarak Tonnies, bu kavramları Weber sosyolojisinde olduğu gibi daha çok ideal tip olarak kullanır (Nisbet, 2013: 98-113; Ayrica bkz. Tonnies, 2019: 42-62; Yelken, 1999: 33-53).

Nisbet'e (2013: 107) göre Gemeinschaft ve Gesellschaft iki kavram olarak hukukî, ekonomik, kültürel ve entelektüel hatta cinsiyetler arasındaki ayrılmayı bile tecessüm ettirir ya da yansitır. Fakat her bir yapının kalbinde, bir sosyal ilişki tipinin imajı ve karşılıklı birbirini etkileyen duygusal etmenler ve iradi zihin unsurları vardır. Amerika'da Demokrasi'nin yazarı Tocqueville için aristokrasi ve demokrasi tipoloji olarak ne anlam ifade ediyorsa, işçi ailelerini çalışan toplum bilimci Le Play için ataerkil ve istikrarsız aile tipleri; Marx için feodal ve kapitalist ekonomik üretim biçimleri; Tonnies için de Gemeinschaft ve Gesellschaft aynı şeyi ifade ediyordu. $\mathrm{Bu}$ sosyolojik anlatılarda, kuşatıcı sosyal düzenin tek bir yönü merkeze alınmakta ve tek bir yöne dinamik bir önem atfedilmektedir. Deyim yerindeyse merkeze alınan bu yön toplumsal gelişimin yeterli nedeni haline getirilmektedir. Mamafih Tonnies'de cemaat sosyolojisinin önemli tarafi ne bu bağlamda ortaya konulan sınıflandırıcı analiz ne de tarih felsefesidir. Asıl önemli nokta, sosyal ve örgütlenme tipleri olarak Gemeinschaft ve Gesellschaft ayrımıla ve bu tipolojileri tarihsel ve mukayeseli olarak kullanmasıyla kapitalizmin, modern devletin ve bir bütün olarak modernist dünya görüşünün sosyolojik izahının yapılmasıdır (Nisbet, 2013: 108).

Tonnies'in yaklaşımı kimi açılardan eleştirilmiştir. Özellikle cemaat, Tonnies'in sosyolojisinin zemininde duran "doğal irade" ve "rasyonel irade" benzeri epistemolojik fikirlerin belirsizliği ve tartışmalı konumları ve bu ikisini birbirini ötekileştirecek şekilde kullanması dolayısıyla eleştirilmiştir. Yanı sıra bu sosyolojide efsaneleştirilmeye yatkın bir "geçmişe özlem" de vardır (Bagnasco, 2011: 130). Yelken'e (1999: 39) göre Tonnies, yaklaşımında cemaatten yanadır ve modern toplumun karşısında yer alacak kadar ideolojik bir tavır içerisindedir. $\mathrm{Bu}$ tavır çalışmalarının her yanına sinmiş, geleneksel cemaatin çözülüşü onu derinden üzmüştür ve modern toplumun gelişini dehşetle karşılayan duygusal bir tutuma itmiştir. Şu bir gerçek ki tüm eleştirilere rağmen yüzyılı aşkın bir süredir yazılan bu sosyolojik metin henüz aşılmış değildir.

\subsection{Durkheim ve Etik Cemaat}

Emile Durkheim (1858-1917) sosyolojisinde cemaat fikri içerik, tipolojik ve metodolojik olarak sahnelenmektedir. Yani Durkheim sosyolojisinde cemaat; ahlak, dayanışma, kollektif bilinç, hukuk, sözleşme, din ve hatta insan zihninin doğası gibi meselelere yeni anlam boyutları kazandırılan bir analiz çerçevesi olmuştur (Nisbet, 2013: 113; Turner, 2010: 354). Onun dünyasinda toplum kavramının gerçek kökleri societas'ta (toplum) değil, communitas'tadır (cemaat). Bir başka ifadeyle, bireyci rasyonalizme bir tepki olarak Durkheim'da, öncelikli gerçekliğe sahip olan şey kollektif cemaattir. Burada Durkheim bireyin en derin hallerinden bazılarını -örneğin dini inanc1, zihin kategorilerini, arzuyu ve intihar etkisinialır ve onları bireyin dışında duran cemaate ve ahlaki gelenekte ikamet eden şeylere göre açıklar.

Özetle; Durkheim sosyolojisinde toplum tam anlamiyla bir "ahlaki/dini cemaat" olarak tasavvur edilmektedir. Bu cemaat için "anomi" büyük günahtır. Anominin artışı cemaatin çökmesi ya da dağılması demektir. Bu cemaatsel tahayyülün ana çerçevesini "mekanik dayanışma"/"organik dayanışma", "anomi"/"bireycilik" ve "cemaatsel otorite"/"kolektif vicdan" gibi kavramlar oluşturmaktadır. $\mathrm{Bu}$ kontekstten dolayı Nisbet, Durkheim'in yaklaşımını "metodolojik cemaat" (2013: 113-133) şeklinde tanımlamaktadır. Ancak Durkheim'in cemaate dair yaklaşımını etik ya da ahlaki olarak kodlamak onun sosyolojisinin ruhuna daha uygun olabileceği kanaati de baskın görünmektedir (Delanty, 2015: 43). Organik dayanışma ve mekanik dayanışma dikotomisinin inşasında Tonniesçi izler bulmak mümkündür. Sonuç olarak bu sosyoloji, özellikle Dini Hayatın İlk Şekilleri (2009) üzerinden modern toplumsal yapıların kendilerine dönük öz-düşünümsel tutumların ifadesi olarak okunmaktadır. Başka bir ifadeyle toplumsal yapının düşünümsel birçok zengin fikir arasında, toplumun kendi kendini yeniden doğurduğu ya da ürettiği, dönemsel, toplumsal kaynaşmaların yoğun toplumsal etkileşim esnasında kutsal olanı kendiliğinden yeniden yarattığı ve böylece toplumsal örgütlenmeyi yeniden inşa ettiği görüşü baskın durmaktadır (Tiryakiyan, 2006: 295).

\subsection{Weber ve Rasyonel Cemaat}

Alman sosyolog Max Weber (1864-1920) birbirinden farklı cemaat türlerinin toplumsal yapılarına dair sosyal gerçekliği anlayabilmek için cemaat (community) kavramı üzerinde durmaktadır. Onun yaklaşımında merkezi tema "toplumsal ilişki"dir (communal relationship). Zira Weber'in toplum tanımının temeli "toplumlaşma"dır. Yani, her bireyin eylemi, anlamlı içeriğiyle, başkalarının eylemini dikkate alan ve buna göre yönlendirdiği için aktörlerin çoğulluğunun davranışını yansıtan "toplumsal ilişkiler"dir (Swingewood, 1998: 175). Weber'e göre toplumsal davranma eğilimi (duygusal veya geleneksel) bir ortak aidiyet duygusuna dayanıyorsa bu ilişki cemaat ilişkisi olarak tanımlanabilir. Eğer davranma eğilimi (değerlere oranla veya araçsal nedenlerle) rasyonel olarak gerekçelendirilmiş bir çıkar bağından doğuyorsa bu ilişki "birlik"/“cemiyet" olarak tanımlanır (Bagnasco, 2011: 130; Weber, 2012: 150) Cemiyet karşılıklı muvafakat yoluyla kurulan rasyonel bir anlaşmaya dayanır. Rasyonelliğin söz konusu olduğu bu durumlarda birey davranışına ya bu anlaşmanın kendini bağladığına inanarak değer-bilinciyle ya da karşı tarafın anlaşmaya sadık kalacağını umarak gaye bilinciyle eyleme yön verir (Weber, 2007: 80). 
Weber, cemaati hem geleneksel hem de gelenek ötesi yorumlara alan bırakacak şekilde tanımlamıştır. $\mathrm{Bu}$ bağlamda Tonnies'in yaklaşımından etkilenmiş olmakla birlikte ondan farklılaşan yeni yorumlarda ortaya koymuştur. Buna göre Weber sosyolojisinde gelenek ile modern dönem arasındaki fark, Tonnies'in düşündügüunün aksine topluluğun ortadan kalkmış olması değil, akışkan sosyolojinin zemininde yeni tipte bir topluluğun oluşuyor olmasıdır (Delanty, 2015: 45; Giddens, 2016). Weber'e göre, ekonomik anlamda gelenekselcilikten uzaklaşma hem dini geleneğe hem de bütün geleneksel otoritelere başkaldırma destekleyici bir öge olarak görülüyor. Fakat genellikle unutulan bir noktayı vurgulamak gerekir: Reform, kilise otoritesinin yaşam üzerindeki etkisinin tamamıla yok edilmesi değildir; var olan biçimin yeni bir anlam kazanmasıdır. Çok rahat bir şekilde gerçekleşen değiştirme, o zamanlar bir uygulama olarak varlığ hissedilmeyen, birçok durumda yalnızca biçimsel olan bir otoritenin, özel ve toplumsal yaşamın bütün alanlarında gözlenebilir ölçüde etkili olan, sonsuz derecede güçlü ve yaşamın bütün biçimlerine etkisi olan bir otoriteye yerini vermesidir (Weber, 2014: 35). Modern cemaatin prototipi bürokrasidir. Geleneği ise Kalvinistler temsil eder. Sonuç olarak Weber'in cemaat kavramı ve onun antitezinin özel kullanım tarzına baktığımızda Gemeinschaft ve Gesellschaft tiplemesi Tonnies için ne ise bu ilişki tipolojisi de Weber için odur. Onlar sosyolojik formasyon açısından ideal tiplerdir (Nisbet, 2013: 110).

\section{Model, Toplum ve Kavram}

Sosyolojik düşünme geleneği model üzerinden düşünmeye yatkındır. Model odaklı düşünme biçimlerinde modelin kendi içinde bütün olması esastır. Bütün, parçadan öncedir ve tikel olguların anlamlandırılması belirli bir modelin çizdiği sınırlar içerisinde gerçekleşir. Toplum üzerine ya da toplum odaklı düşünüş biçimlerinde de benzer bir durum söz konusudur. "Toplum” belirli bir düşüncenin içerisinde anlamlı durmakta, içlemini söz konusu düşüncenin sınırlarında açmaktadır. Alain Badiou "Model Kavramı (2015)" isimli kitabında, model/ler/in katıksız ideolojik yapılar olduğunu belirtir. Gerek topluma gerekse pozitif bilimlere ait modeller, mutlaka bir ön-belirlenimden hareket ederler. Salt olgulara dayalı bir modelden söz etmek olanaksızdir.

Sosyolojiye dair anonimleşen, dolaysızca kabul gören yargıların başında sosyolojinin konusunun "toplum” olduğu yargısı gelir. Oysa bu düşünce yanlış olmasa bile eksiktir, çünkü sosyolojik modeller toplumu da içeren bir bütüne (toplumsal olana) dayanırlar. Sosyolojik modeller sadece "toplum"la ilgilenmez, "toplum"u "toplumsal olan"1n bir kategorisi şeklinde düşünürler.Toplum sosyolojik modellerde tarihsel olarak tekil bir toplumsal birlikteliğin imgesel adıdır. "Toplumsal olan" ise tarih ve kültür kodlarına koşut olarak farklı şekillerde, ait olduğu kültür ve tarihin yapısına özgü var olma ve görünme biçimleri bulunan daha kuşatıcı bir fenomendir. İnsanlar, tarihsel süreçte "toplumsal olan"ın çatısı altında farklı "toplumlar" oluşturmuşlardır. "Toplum” kavramını en üst kavram olarak kabul ettiğimizde, tarihin belirli bir döneminde, belirli bir kültürün kodlarıyla kurulmuş olan bir fenomeni merkeze almış olur ve böylece insanlık durumlarının sosyolojik süreçlerini göz ardı etmiş oluruz.

Sosyal bilimlerde "toplumun kuruluşu"nun toplum öncesini tarihsel olarak belirlemekte genellikle bir sorunla karşılaşılmamaktadır ama toplum söz konusu olduğunda, neredeyse tarihin başından itibaren verili olan ontolojik bir yapıdan/birimden söz edildiği yanılgısına düşülür. $\mathrm{Bu}$ nedenle toplumu sosyolojinin mutlak bir nesnesi haline getirmek, toplumun kuruluşunu, neredeyse bir yaradılış hikâyesi bağlamına yerleştirmek tarihsel bir inşa olarak toplum gerçekliğinin mistifiye edilmesiyle sonuçlanır (Çiğdem, 2006: 7). Neticede toplumun ya da toplumların varlığ 1 ve varlığını sürdürmesi bir taraftan insanla irtibatlı olan bir şey olmakla birlikte, öte yandan insandan olduğu kadar fizikî dünyada mevcut olan şeylerin varlığı ve bu varlığını sürdürmesinden de farklıdır (Görgün, 2006: 169). İnsan bilimlerinin (manevî bilimlerin) gerek oluşum süreci gerekse araştırma yöntemi doğa bilimlerinden farklıdır (Dilthey, 1999) ve temelde insan gezegeninde iradî ve aklî bir varlık olarak insanın olanaklarının ya da ait olduğu yapıların ve anlam dünyasının tartışma veya inceleme konusu edilmesidir. Dolayısıyla sosyolojik süreçlerden fizikî dünyada bulunan bir gerçeklikmişçesine söz edilemez. Bunları, insanın olanaklarını ya da olanaksızlığını inceleyen modeller şeklinde düşünmek gerekir. Dolayısıyla kavramlar ait oldukları sosyolojik modellerin yedeğinde ve tarihsel oluşumları dikkâte alınarak okumalıdırlar.

\section{Tanımlar ve Refleksif Açılımlar}

Bilindiği üzere Tonnies ile özdeşleşen "Gemeinschaft" ve "Gesellschaft" geçiş ya da ilkinin sonrakine dönüşümü sosyolojisi, beşerî birlikteliğin toplumsal varoluşun birbirinden bütünüyle iki farklı modeline atıfta bulunur. Cemaatde bir yapı ve kavram olarak tıpkı toplum gibi özgül tarihsel bir sürecin ürünüdür. Ancak bir birliktelik formu olarak toplumdan daha önceliklidir. Yani cemaat, sosyolojik düşüncede insanlık tarihinin toplum öncesi evresini de kapsayacak şekilde yayılabilecek bir "varoluşsal yapı" olduğu farz edilmektedir. $\mathrm{Bu}$ açıdan toplumsal kanonlarda gelişen bir olgu olarak cemaat, doğasında kutsallık, değer ve muhafazakârlık barındıran bir yapı şeklinde karşılık görmektedir. Tonnies’te (2019: 447) de böyledir. Bu bağlamda cemaat insan iradesine dayalı uyum, örf ve din olarak tasvir edilir. Cemaatin seküler yüzü daha çok "topluluk" kavramı ile tanımlanmaktadır (Aydemir, 2011: 78). Buradan cemaate dair seküler karşıtı ve tamamen kutsal olan bir anlam çıkarılmamalıdır. Elbette seküler olan cemaat vardır. Seküler dahi olsa her cemaat, varlığını sürdürebilmek adına toplumsal içerikte anlaml1/meşrulaştırıcı bir metafiziğe ihtiyaç duyar. Cemaat güven toplumu inşa etmeye dönük bir sosyoloji olarak kendi toplumsal bağlamında aşkın/kutsal kabul görenden parçalar taşır. $\mathrm{Bu}$ özsel durum cemaat kavramının otantik/odak noktasıdır.

Cemaat (topluluk/community) terimi tartışmalı bir kavramdır. Onun evrensel düzeyde kabul gören bir tanımını yapmak zordur. Zira cemaat toplumsalın yeniden biçimlenişine bağlı olarak çok anlamlı bir boyut kazanmıştır.Örneğin 19. yüzyıl sosyolojisinde, ulus devlet müktesebatına uygun olarak mekân/toprak unsuruna bağlı 
bir şekilde tanımlanmaktadır. Günümüzde ise (geç modern dönemde) dinî, etnik, yerel, ulus altı veya ulus ötesi gibi yeni sosyolojilere bağlı olarak cemaatin anlam alanları genişlemektedir (Yelken, 1999: 11). Esasen cemaat Kuhncu anlamda bir paradigmadır. Genellikle ortak ve refleksif bir kimlik ya da dünya görüşü temeline dayalı benzer ilgilere sahip özel olarak oluşturulmuş ve birbirleriyle sistematik bir etkileşim içinde olan insan gruplarını betimlemektedir (Giddens, Sutton, 2014: 227; Marshall, 1999: 90).

Türkçede bugün kullanmakta olduğumuz cemaat kavramı ise "toplamak, bir araya getirmek" anlamındaki "cem" mastarından türeyen Arapça bir isim olup sözlükte "insan topluluğu" mânâsına gelmektedir (Uzunpostalcı, 1993). Cemaatin çeşitli sözlüklerde bu tanımındaki içeriğe benzer içerikler görülmektedir: Topluluk, aynı düşünce etrafında bir araya gelen, insan kalabalığı, bir dinden ya da soydan olanların hepsi, din kardeşliği esasına dayalı olarak sevgi ve saygı temelli gerçekleştirilmesini istediği birlik, beraberlik, bir ülkede yaşayan dinî azınlık (Serinsu, 2009: 47: Doğan, 1994: 115) gibi anlamlara gelmektedir.Toparlayacak olursak genel anlamda cemaati aynı inanç, değer ve davranış kalıplarını benimsemiş, karşılıklı olarak yakın, içten, yüz yüze ve samimi ilişkilerle birbirine bağlı insanlardan oluşan, topluma oranla görece küçük, homojen insan topluluğu şeklinde tanımlamak mümkündür (Demir, SBS).

Batılı sosyolojinin bir kısmında pragmatizm temelli tanımlara rastlamak mümkündür. Örneğin, Parsonsyen anlamıyla cemaat hayatla ve çıkarlarla ilgili olan ve pek belirlenmemiş bir alandaki kapsamlı bir dayanışma ilişkisini anlatmak üzere sık sık kullanılan bir kavramdır (Marshall, 1999: 90). Dolayısıyla cemaat tüm eksikliklerine rağmen bir sosyolojik gerçeklik (Blanchot, 1997: 14) ve aynı zamanda tahayyül biçimi olarak hem toplumsal pratikleri ve grameri inşa hem de onları anlama ya da anlamlandırma imkânı bağlamında karşımıza çıkmaktadır. $\mathrm{Bu}$ bağlamda sosyolojide cemaatten bahsedildiği zaman diğer sosyal organizasyon şekillerinden ayırt edilebilen farklı bir toplumsal örgütlenme yapısına işaret edilmektedir (Macler ve Page, 1969: 6). Bu bağlamda Yelken, Cemaatin Dönüşümü (1999: 259) adlı çalışmasında Thomas Bender'in tanımından mülhemle cemaati tanımlamaktadır. $\mathrm{Bu}$ kontekste cemaat iyimser bir olasılıkla "karşılıklı ve duygusal bağlarla temelli toplumsal ilişkiler şebekesi (network) olarak" tanımlanmaktadır. Bu yaklaşımda insanın çevresi ya da toplumsal ilişkiler ağı cemaatin özüdür. Yelken'e göre bu tanımlama yereli aşan bir yerde durmaktadır. Bu bağlamda herhangi bir zaman ve mekanla sınırlı olan aile, komşuluk, kabile, köy ve dini gruplar gibi tikel gerçeklikler, tümel gerçeklikler dolayımında özgül yapılar olarak kabul görmektedir.

Sosyolojik evrende kurumlar/yapılar ayrıca, tarihselliği ve kontrolü ihtiva eder. İnsanî eylemlerin karşılıklı tipleştirilmeleri, paylaşılan bir tarihin akışı içerisinde oluşturulur. Bunlar, anlık bir buluş gibi birden ve zamansız bir şekilde yaratılmazlar. Kurumlar/yapılar/fikirler, daima bir tarihe sahiptirler ve o tarihin ürünleridirler. Dolayısıyla bir yapıyı, içinde üretildiği tarihsel süreci anlamaksızın onu layıkıyla anlamak imkânsızdır (Berger ve Luckmann, 2008: 83). Dolayısıyla Batı'da cemaat, Hobbes'un Levithan'ında
(2012) ve Rousseau'nun Toplumsal Sözleşme veya Siyasal Hukukun Prensipleri (2016) çalışmalarında ortaya konulan aydınlanmacı sözleşme geleneğine uygun bir biçimde pozitivist ilerlemeci dikotomik yapı üzerinden 19. yüzyılda sosyoloji disipliniyle birlikte yeniden üretilmiş bir fikirdir.

Bu sosyolojik kanon, İslâm dünyasında da kendi epistemik tefsirine uygun bir şekilde yorumlanmıştır. Bu yaklaşımın en somut epistemolojisini sosyolojinin göz ardı edilen kurucu bir müverrihi olan İbn Haldun'un Mukaddime'sinde görmekteyiz. Bilindiği üzere İbn Haldun'da toplumsal kökenler kavramının temelinde "asabiyet" vardır (İbn Haldun, 2011: 334; Canatan, 2009: 99) ve bu yaklaşım biçiminde belirleyici olan doğa durumu bireyci değil, cemaatsel/kabileseldir. Bozarslan'a (2016: 49,50) göre, bu tasvir bize topluluğun kökenleri hakkında son derece özgün bir okuma sunmaktadır. Asabiyet, hem bir grubun -cemaat olma bağlamında- bütünleştirici gücü, hem grubun kendi özgüllüğü ve ortak amaçlar hakkındaki bilinci, hem de iktidar yolunda onu ister istemez harekete geçirip yansıtan gerilim anlamlarına gelir. Benzer biçimde asabiyet kavramı oldukça diyalektik bir bileşendir. Onun gerçekleşmesi, kendisine içkin çelişkilerin etkisiyle döngüsel bir şekilde kendi kendini var ettiği gibi yok etme sürecini de başlatır.

Burada yer alan cemaat kavramı ile salt mahalli cemaatin çok ötesine uzanan bir şey kastedilmektedir. Başka bir ifadeyle cemaat, mahalli cemaati içerir ama din, çalışma hayatı, aile ve kültürü de kapsama alanına dâhil ettiği için mahalli cemaatin ötesine gider (Nisbet, 2013: 7). Yanı sıra cemaat kavramı, 19. ve 20. yüzyıl Batı düşüncesinin bir kısminda görüldüğü üzere, yüksek derecede şahsî yakınlığın, duygusal derinliğin, ahlaki sorumluluğun, sosyal insicam ve zamanda sürekliliğin karakterize ettiği bütün ilişki biçimlerini kapsar. Cemaat, bir sosyal düzende oynayabileceği şu ya da bu rolleri ayrı ayrı üstlenen bireyden ziyade, bütünlüğü içinde algılanan insana dayanır (Nisbet, 2013: 66). Kısacas1, sosyolojik düşünceye göre, bir bütün olarak toplumsallığın kendisi insani bir üründür. Toplum nesnel bir gerçekliktir. Buna göre toplum yoksa insan da yoktur; bu nedenle insan, toplumun usturlabıdır. Yine bu sosyolojik durum pekâlâ açıktır ki, bu üç momentten herhangi birini ihmal eden bir sosyal analiz, yanıltıcı bir analiz olacaktır (Berger ve Luckmann, 2008: 92). Cemaat sosyal ve psikolojik gücünü, salt irade ve çıkardan daha derin özellikler arz eden bu üç momentten ve burada hâsıl olan motivasyon/hareket düzeylerinden alır. Ayrıca cemaat, bu sosyo-psikolojik gücü hayata geçirmeyi, çeşitli kurumlarda olduğu gibi salt elverişlilik ya da onayla mümkün olmayan bireysel iradenin bastırılmasıyla gerçekleşir (Nisbet, 2013: 66).

Öte yandan burada dile getirilen cemaat dünyasında bireysel iradenin baskılanması meselesi bazı sosyologlar tarafından çokça kabul görmemektedir. Risk toplumu kuramcısı Ulrich Beck'e göre, bireycilik mutlak manada bir "cemaat karşıtlığı"nı ifade etmediği gibi, tersine, bir cemaate girmek de bireyciliğe halel getirmeyebilir (Günerigök, 2018). Esasen bu noktada, cemaatin içinde yer aldığ1 kurumsal dünya, meşrulaştırılma, yani 'açıklanabileceği' ve 'haklılaştırılabileceği' yollara gereksinim duyar. Bunun sebebi, kurumun daha az gerçek görünmesi değildir. $\mathrm{Bu}$ bağlamda sosyal dünyanın 
gerçekliğinin aktarımı esnasında bir heybet kazanır. Ancak bu gerçeklik kısmen Nisbet'in de değindiği gibi yeni kuşağa biyografik bir hatıra olarak değil de bir gelenek olarak ulaşması anlamında tarihsel bir gerçekliktir (Berger ve Luckmann, 2008: 66,67).

\section{Cemaatin Kuruluşu}

Tüm kavramlar gibi, cemaat kavramı da tarihle, zaman ve mekânla ilişkilidir. Bu kavramın ne zaman başladığı ile ilgili kesin bir tarih belirlenememektedir. Antik Yunan döneminden aydınlanma çağına kadar cemaat toplumun karşı savını değil, temelini yansıttığı çok iyi bilinmektedir. Başka bir ifadeyle tarihin erken zamanlarından beri insanlar cemaatsel yaşam hakkında düşünmekte ve bu yaşamın kuramını geliştirmektedir. Modern sosyolojide cemaat kavramı, Batı'da sözleşme düşüncesinin Aydınlanma Çağı'nda sahip olduğu yön tayin edici öneme sıkıntılı süreçler sonrasında ve özellikle 19. yüzyılda otorite olmayı başarmış ilerlemeci bir söylemdir (Nisbet, 2013: 65).

Cemaatin doğuşu sorunsalı İbn Haldun'da daha farklı bir boyutta değerlendirildiği görünmektedir. İbn Haldun, Aristotelesçi bir yaklaşımla cemaat/toplumun insanın doğasından çıkan bir olgu olduğu tezi savunmaktadır. Buna göre cemaat ve asabiyet (grup/cemaat hissi/kabile ruhu/grup dayanışması) sosyolojisi arasında seçici yakınlık bulunmaktadır. $\mathrm{Bu}$ açıdan İbn Haldun'da cemaat, kurumların oluşum temelleri dolayımında "nesep asabiyeti" ve "sebep asabiyeti" gibi iki farklı toplumsal kanon üzerinden değerlendirilmektedir. İlk biçimi soy/baba tarafından akrabalığı ifade eden bir harekettir. İkincisi ise aralarında nesep bağı olmayan kişilerin başka temellerden ve motiflerden hareketle bir araya gelerek bir takım/millet ruhu oluşturmalarıdır (İbn Haldun, 2011: 334; Canatan, 2009: 99,100). Asabiyet kavramının şemsiyesi altında kır ve kent toplumlarının oluşum ve gelişim sosyolojilerini resmeden "bedevi" ve "hazari" kavramlarını da cemaat sosyolojisi bağlamında zikretmekte fayda vardır. Bu suretle sosyolog Yelken'e (1999: 28) göre asabiyet kavramı ile Tonniesçi anlamda Gemeinschaft'ın temelinde bulunan "doğal irade" kavramı arasında çok yakın bir bağ vardır. Bu tür kavramları, fikir/paradigma yapan şey, tarih ve tarihin görkemli düş kırıklıklarının bu kavramları bize harabeyi çok gerilerde bırakan ve aynı şekilde ütopyaya dönük bir felaket zemininde tanıtmış olmasıdır. Bu nedenle cemaat bir sosyoloji olarak insan hayatının çok önemli bir sorunu ve deneyimidir. İnsanlar ütopyalarının/dünya görüşlerinin ifade ettiği özlemleri arar. Refleksif bir şekilde hem kendi hem de başkalarının sahip olduğu yapıların olabilirliğine inanmaktadır (Blanchot, 1997: 10).

Batı sosyolojisinde insanların nasıl olup da birlikte yaşadığ sorusuna verilen cevaplar arasında, son asırlarda Batı'da kabul görmüş ve buradan da, birçok konuda olduğu gibi bu meselede de İslâm dünyasına geçmiş olan "sosyal antlaşma teorisi" (social contract) rasyonel bir açıklama örneği olarak oldukça dikkat çekicidir. Bu teori insanların birlikte yaşamasının esasını "rasyonel bir antlaşma" teşkil ettiğini ve bu çerçevede bu anlaşmaya iştirak eden insanların zaman zaman bu antlaşmayı gözden geçireceklerini veya geçirebileceklerini ve bunun kendisi kadar yolu ve yönteminin de bir uzlaşma konusu olduğunu söylemektedir. $\mathrm{Bu}$ tutum kendi içinde evrensel bir ilkeyi başından dışladığı için tamamen uzlaşmaya dayalı, konvansiyonel bir süreç öngörmektedir. Bu aynı zamanda kalıcı-evrensel değerlerin reddedilerek bunun yerine duruma göre şekillenmesi uygun olan, tamamen sosyolojik kontekste bağlı, normatif bir esas arayışına rasyonel ahlak arayışı adını vererek bunun araştırılmasını ve keşfini, sadece felsefeye değil, genel olarak bütün bilimlere havale etmek olarak gerçekleşti. Ancak zaman içerisinde meselenin göründüğü veya umulduğu kadar basit olmadığı, özellikle birlikte yaşamanın, yani toplumsal hayatın herhangi bir aidiyet olmadan kalıcı ve düzenli bir şekilde devam edemeyeceği ortaya çıktı (Görgün, 2006: 175-176). Dolayısıyla cemaat Tonnies'te (2019: 42) olduğu gibi insan iradelerinin tam bir birliği görüşü üzerinde temellenerek var olur.

Görgün'e (2006: 176) göre birlikte yaşamak ile aidiyet, birbirinden ayrı iki konudur. Birlikte yaşamak söz konusu olduğunda, farklı olan ve her biri birer taraf olan fertlerin mesela bir şekilde uzlaşarak birlikte yaşadıklarını/yaşayabileceklerini söylemek/varsaymak mümkün olmakla birlikte, birlikte yaşamak ait olmayı gerektirmez. Çünkü aidiyet birlikte yaşamaktan bağımsız olabildiği gibi, birlikte yaşayan insanlar müşterek bir aidiyet hissine sahip olmayabilirler. $\mathrm{Bu}$ bizi aidiyetin birlikte yaşamaktan daha farklı bir boyut olduğu düşüncesine götürmektedir. Ait olmak denildiğinde, sorun daha farklı bir bağlam kazanmaktadır: İnsan başka bir insana değil, insanlar birlikte daha başka bir şeye/metafiziğe ait olarak kendilerini tanımlamakta ve duruma göre- bu aidiyet içerisinde kendilerini "yeniden" kavramaktadırlar.

Tanpınar'ın (2018: 177,178) ifadesiyle "böyle bir mevzu ister istemez bir tenkit fikrini, hatta onun üstünde bir şeyi, bir iddiayı taşır. Fakat bununla da kalamaz. Çünkü cemiyet hayatını bütün müesseseleriyle görmek lazım gelir." Dolayısıyla sosyal antlaşma tezi, insanların neye ait olacakları kadar bu aidiyetin formlarını da kendilerinin iradî olarak belirlediklerini varsaydığ 1 hâlde, bu varsayımın Hobbes, Rousseau, Locke ve Kant gibi önde gelen düşünürleri, siyasî olarak absolutizmin ve siyasî otoritenin toplumsal varoluşu önceleyen ve onu mümkün kılan bir ilke olduğu hususunda müttefiktirler. Bu çerçevede hem hukuk alanını hem de toplumsal normları ve dolayısı ile toplumsal düzeni doğrudan siyasî otoriteye endeksli bir şekilde düșünebilmekte idiler. $\mathrm{Bu}$ düşünce Yeni Çă̆ Batı düşüncesini olduğu kadar, Batı'daki toplumsal hayatı da bütün boyutları ile belirlemiştir (Görgün, 2006,176). Bauman'a göre bu doğrultuda gerçek anlamda cemaat olamayan bir dünyada kurgulanmış olan, insanları içinde kategorize ederek, sinıflayarak, dosyalayarak, topluluklara ayırarak fark yaratan farkları seçerek kendi yaşamsal çevresini biçimlendiren ve dünyayı önceden hazırlamış bir varlık olarak "Hobbes insanı" ile hiç kimse karşılaşmamıștır. Yani toplum öncesini toplumsaldan nasıl ayırabiliriz? $\mathrm{Bu}$ bizce belirsiz bir durumdur. Burada Heidegger'e referansla şöyle diyebiliriz ki “tüm varlık âlemi birlikte anlamlıdır." Dolayısıyla tarih, Hobbes'ın haklılığını ya da haksızlığını teyit etmiyor; hatta teyit etmesinin hiçbir yolu da yoktur (Bauman, 2017: 75). 
$\mathrm{Bu}$ çerçevede cemaat, duygu ile düşüncenin, gelenek ile bağlılığın, mensubiyet ile iradenin kaynaşmasıdır. O, sembolik ifadesini bir yerde/bölgede, dinde, ulusta, rrkta, meslekte ya da mücadelede/davada bulabilir (Nisbet, 2013: 66). Nisbet'e göre sosyolojinin en esaslı sorusu, cemaatin nasıl “mümkün” olduğudur. Görgün'ün yaklaşımında böyle bir soru, tamamen metafizik bir sorudur ve varlığın temel üç kipinden (siga, modus veya modi) birini teşkil eder. İnsanların nasıl olup da bir arada yaşayabildikleri, belki sorunun bir cihetini teşkil etse de, toplumun aynı zamanda bir kimlik/ahlak/inanç ciheti olduğu dikkate alındığında, meselenin sadece "bir arada yaşama" meselesi olmadığı; bunun ötesinde, meselenin bir "aidiyet, kimlik ve inanç" yönlerinin olduğunu söylemek mümkündür. Toplumsallığın nasıl mümkün olduğu sorusu, aynı zamanda nasıl olup da insanların kendilerini "bir şeye" ait olduklarına inandırdıkları ile ilgili bir soru olarak ifade edilebilir. Dolayısıyla bu doğrultuda bir arada yaşama meselesini, aynı zamanda bir aidiyet, ahlak ve inanç meselesi olarak görmek mümkündür (Görgün: 2006: 175: Bauman, 2017: 69: Durali, 2000: 34). Bu sosyolojinin hem tarihi hem de sembolik olarak arketipi "aile"dir. Hemen hemen her gerçek cemaatte, ailenin şeceresi büyük önem arz eder. Aynı sosyal muhitte, komünal-olmayan yarışmada ya da çatışmada, faydada ya da sözleşmeye dayalı rızada şekillenen gerçek veya hayali antitez, cemaate bağlılı̆̆ın gücünün görünmesi ve korunması açısından çok önemlidir. Görece gayr-1 şahsilikleri ve anonimlikleriyle bütün bunlar, cemaate bağl1lıkları göz önüne çıkarmaktadır (Nisbet, 2013: 66).

Cemaat, kimlik, aidiyet, ahlak ve inanç meselesinin ne olduğu ve meselenin nasıl çözüldüğü sorusunu tam ortaya koyabilmek için, bir hususun daha netleştirilmesi gerekmektedir: bilindiği üzere aidiyet/kimlik, kabaca bir veya birden fazla kişinin bir araya gelerek bir veya birçok konuda gerçekten ya da fiktif (kurgusal) olarak uzlaşması değil, fertlerin (kendilerini) fertleri aşan daha üst bir şey/metafizik ile müşterek bir cihetten irtibat kurmaları anlamına gelmektedir. Bu üst irtibatın hareket cevheri "ahlak"tır. Zira ahlak bireye bir kimlik ya da aidiyetin tasavvurunu vermektedir. Dolayısıyla ahlak ontolojiden önce gelir. Ahlak fitrattandır ve o olmadan insan yoktur. Ahlak ve aidiyeti/kimliği bir imkân haline getiren şey ise Topçu'nun (2017) ifadesiyle "hareket”tir. Zira hareket insan ile Tanrı'nın bir terkibidir. Bu bağlamda toplumsal hayatın temelini oluşturan ahlak/din, semanın barış ve derinliğiyle ahenk içinde hareket etmesi için insana yöneltilmiş bir taleptir. Bu talebin uygulayıcısı ise insandır. $\mathrm{Bu}$ nedenle cemaat, kendi başına yoktan var olan bir yap1 değildir (Görgün, 2006: Durali, 2000: 34; Bircan, 2018: 64). Cemaat, insanların gerek varoluşları gerekse görevleri bakımından bir araya gelişleriyle ortaya çıkan bir toplumsal olgudur.

Bütün bunları söyledikten sonra, burada kısa bir parantez açabiliriz. Aidiyet/kimlik, ahlak ve inancın sonradan kurgulanan değil, insanı önceleyen ve varoluşuna zemin teşkil eden metafizik anlamda olgusallıklar olduklarının fark edilmesi ile birlikte birçok düşünür, cemaatin oluşumunu bir "dil" ve hatta "1rk" meselesi temelinde ele aldığı görülmektedir. Ancak aynı dili konuşan veya aynı 1rka mensup birçok toplumun, daha üst bir toplumsal varoluş şekli olarak bir cemaat (devlet) oluşturamadıkları gibi, farklı dil ve ırka mensup insanların bir cemaat veya ümmet oluşturabilmeleri gerçeği, toplumu, toplumsal olguları/müesseseleri dil ve 1rk zemininde temellendirmeye çalışmak bir yönüyle 19. yüzyıl ulusalcı, ilerlemeci pozitivist sosyolojinin mutlaklaştırılması anlamına geldiğini ifade edebiliriz. Esasen bugün küresel ölçekte yaşanılan sosyoloji bu ciheti hem sistematik hem de tarihi anlamda geçersiz kılmaktadır. Örneğin bu bakış açısına esas teşkil eden Batı Avrupa'nın kendi geçmişinin, özellikle Avrupa Birliği veya Avrupa'nın birleştirilmesi sürecinin önündeki en büyük engel hâline gelmesi, ortaya bir dilemma çıkarmışa benzemektedir. Batı Avrupa, bir yönüyle varlığını ve yükselişini dil ve ırk temeline bağlı ulus devlete borçlu iken, şimdi varlığını devam ettirmesinin önündeki en büyük engel olarak ulus devlet yapısını görmektedir. $\mathrm{Bu}$ noktada Avrupa Birliği'nin en önemli sorunu yerel Avrupa dilleri ve ırklarını aşan bir aidiyet/kimlik/ahlak/inanç perspektifi "oluşturmak" şeklinde ifade edilebilir (Görgün, 2006: 179).

Hülasa edecek olursak analitik bir kavram olarak cemaat, belli başlı dört kabule sahiptir: toplumsal ilişkilerin özel bir tipi, ileri derecede bütünleşmiş bir toplumsal grup, toplumun özel bir biçimi, yerel bir toplum. Bu dört kabulün hepsi de Tonnies'in cemaat fikrinde vardır. İnsan iradesi ona göre iki biçimde ortaya konulur: doğal irade ve rasyonel irade. Bu iradeler, gerek gerçek ve organik yaşam (cemaatin özü), gerekse ideal ve mekanik biçim (toplum) olarak anlaşılabilecek olan insanlar arasındaki ilişkilerin kurulmasında ve insanların bir araya gelişlerinde etkindirler. Cemaat bir tür canlı organizma iken, toplum yapay bir üründür. Diğer sosyal sistemler gibi cemaat ilişkileri de mahrem, özel ve münhasırdır. Bu durum ortak ve karşılıklı duyguları beraberinde getirir. $\mathrm{Bu}$ çerçevede bireylerin kendiliğinden işbirliği iradesiyle bağlı oldukları cemaate özgü bir iradeden de söz edilebilir. Cemaat ilişkilerinin sonul içeriği, "ifade edilemez, sonsuz ve anlaşılmaz"dır (Bagnasco, 2011: 130). Doğal olarak bu durum sosyal sistemde ortaya çıan alt sistemlerin özerkleşmesini kaçınılmaz kılmaktadır. Çünkü bir sistemdeki aşırı-karmaşıklık ya da çok anlamlılık ve belirsizlik toplumların işlevsel ayrımlaşması için zorunlu önkoşuldurlar (Vandenberghe, 2016: 18; Bozarslan, 2016: 28) .

Ayrıca cemaat ilişkilerinin bir araya gelişi üç başlık altında toplanabilir: kan bağına, coğrafyaya ve dünya görüşüne dayalı cemaatler. Cemaatçi toplumsal gruplar, yaş, güç ve bilgelik farklılıklarına göre içlerinde bir takım özel statüler yaratır. Söz konusu olan, insanların gerekli gördükleri bir birlik nedeniyle bağlı oldukları, ileri derecede bütünleşmiş gruplardır. Toplum temelli gruplarda ise durum bunun tam tersidir. Bunlarda insanlar barışçıl olarak bir yaşam için sözleşmeye dayalı bağlar kurarlar, ancak aralarında var olan daimi bir gerginlikle esas itibariyle ayrı yaşarlar (Bagnasco, 2011: 130). Bu temeller üzerinde cemaattoplum çifti toplumun karşıt iki biçimini tanımlamaya ve modernleşme sürecini birincisinden ikincisine geçiş olarak yorumlamaya varır. Burada üçüncü bir geçiş süreci daha söz konusudur. İkincisinden üçüncüsüne doğru bir yorumlama biçimi ile karşı karşıyayız. Sonuç olarak modern dönemde yaşanılan değişimin yorumlanması için 
Tonnies'in ve çağdaşlarının ortaya koydukları tipoloji, çağın diğer tanımlamaları arasında yeniden yorumlanabilir.

Blanchot'a (1997) göre cemaat arayışlarının temelinde "yetersizlik" ilkesi vardır. Toplumsal varoluş imkânına hükmeden ve bu imkânı düzenleyen temel bir ilkedir bu. Esasen sosyolojide "yetersizlik" düşüncesi bir cemaat arayışı için gereklidir. Ancak bu ilke "ayırıcı" olmayan bir özelliktir. Yani yetersizlik tek başına yeterli bir koşul değildir. Yetersizliğin yanında ikinci bir ilkeye/yasaya daha ihtiyaç vardır. O da Bauman sosyolojisinin temel diskuru olan belirsizlik düşüncesidir. Belirsizlik, insan yaşamının doğal habitatıdır. Ondan kaçma umudu ise insan yaşamındaki arayışların saikidir. Belirsizlikten kaçmak, yalnızca zımnen varsayılsa bile, din/cemaat dâhil her türlü karma mutluluk hayalinin en önemli bileşenidir. Gerçek, muntazam ve eksiksiz mutluluğun her zaman belli bir mesafedeymiş gibi görünmesinin nedeni de budur. Malum ufuk gibi, ne zaman yakınlaşmaya çalışsanız uzaklaşır (Bauman, 2017: 157; 2011: 36; 2000: 242).

\section{Sonuç}

Cemaat sosyolojisi bir güven toplumu arayışıdır. Cemaat, Nisbet'e göre sosyolojik düşünce geleneğinin en önemli kavramıdır. Buna rağmen kavram sosyolojik düşünce tarihi içerisinde sınırları açık bir şekilde ortaya konulmamıştır. Tanım konusunda ciddi sayılabilecek bir belirsizlik söz konusudur. Cemaat kavramı, toplum, grup ve topluluk gibi sosyolojik kavramlarla karıştırılmakta ve ayrıca çeviri literatürde de ciddi sayılabilecek bir kafa karışıklığı olduğu gözlenmektedir. $\mathrm{Bu}$ çalışmada modelin tarihsel bağlamı üzerinden öncelikle kavram ile ilgili tanım konusunda bir perspektif ortaya koymaya çalıştık. Dolayısıyla yaptığımız araştırmaya göre kavramın sabit ve tarih dışı bir şekilde tanımlamanın olanaksız olduğu ve bu nedenle refleksif ve tarihsel bir şekilde tanımlanması gerektiği düşüncesini ileri sürdük. Çünkü kavramların tarihsellikle yakın bir rabıtası var ve bu nedenle sürekli bir şekilde hem içlem ve hem kaplam bakımından yenilenmesi gerekir.

Çalışmada ulaştığımız sonuçlardan biri de cemaatin doğuşu meselesinde tarihsel anlamda Batı ve İslam dünyasında farklı rabıtaların olduğu düşüncesidir. Buna göre Batı düşünce tarihinde moderniteyle birlikte Hobbes ve Rousseau gibi düşünürlerin etkisiyle "toplumsal sözleşme" sonucu cemaatin doğduğu tartışılmaktadır. İslam dünyasında ise İbn Haldun'un tezinin baskın olduğu ve buna göre cemaatin döngüsel tarih evreninde asabiyete bağlı olarak sürekli bir şekilde yeniden üretilmektedir. Ayrıca Batı sözleşme kültürüne dayalı bir kuruluşun zorluğuna dikkat çektik. Yanı sıra Baumancı bir perspektifle cemaatin toplum öncesi durumunun belirsizliğini koruduğunu ve bu nedenle cemaatin kuruluşunun toplumsal sözleşme olgusuna dayalı bir okumanın sorunlu bir okuma biçimi olduğunu dile getirdik. Buna karşılık cemaatin ortaya çıkışı, pragmatizm temeli bir okumadan ziyade; aidiyet, kimlik ve inanç temelli bir hermeneutikle anlaşılabilir. İnsanın varoluşsal anlamda yetersizliği ve belirsizlik düşüncesi sonucu ontolojik güven arayışına girdiği görülmektedir. Asabiyet üzerinden ortaya çıkan hareketin cemaatin doğuşunda etkin olduğunu ifade edebiliriz.
Son olarak cemaat sosyolojisi üzerine dört örneklem prototip üzerinden meseleyi genel bir bağlamdan hareketle tartışmaya çalıştık. Bunlar Batı sosyolojik düşüncesinin en önemli kurucu sosyologları olan Comte, Dukheim, Tonnies ve Weber'dir. Comte Tonnies'ten önce olduğu için bilinçli bir tercihtir. Zira, Comte'un okuması bize Tonnies öncesi cemaat algısını verebilir. Tonnies ise bilindiği gibi cemaat sosyolojisinin en önemli kurucu sosyoloğudur. Weber ve Durkheim ikilisi kendisinden çok ciddi bir şekilde etkilenmişlerdir. Tonnies olmadan bir cemaat sosyolojisi okuması yapmak çok zor bir durumdur. Ayrıca Tonnies kendisinden sonra cemaat kavramı üzerine çalışan tüm sosyologları etkilemiş bir düşünürdür. Sonuç olarak Comte liberal muhafazakâr bir sosyoloji arayışı içerisindedir. Tonnies ise insan yaşamının doğasına en uygun dünya görüşünün Gemeinschaft olduğunu iddia eder. Gemeinschaft, Gesellschaft karşısında zayıflaması Tonnies'i duygusal anlamda yeni bir cemaat arayışına sürüklemiştir. Onun hayatının sonlarına doğru Marksizmde karar kıldığına dair çıkarsamalar vardır. Bu bağlamda Durkheim ve Weber'de durum çok farklı değildir. Bu iki büyük sosyolog da modernitenin güçlenmesiyle birlikte geleneksel yaşam formlarının çok ciddi bir şekilde zayıflayacağını düşünmektedir. Kollektif kimlik/cemaat zayıflayınca yerini anomiye bırakacaktır. Mekanik dayanışmaya dayalı cemaat yerini organik dayanışmaya dayalı topluluğa bırakacaktır. Weber'de ise modernlikle birlikte ortaya çıkan büyü bozumu ve rasyonelleşmenin gelişmesi ile birlikte geleneksel yapılar yerini yeni formlara bırakacaktır. Bunun somut örneği ise demir kafes ve yeni bürokrasidir.

\section{Kaynakça}

Arslan, H. (2007). Epistemik Cemaat: Bir Bilim Sosyolojisi Denemesi, İstanbul: Paradigma Yayınlar1.

Aydemir, M. A. (2011). Sosyal Sermaye -Topluluk Duygusu ve Sosyal Sermaye Araştırmast-, Konya: Çizgi Yayınları.

Badiou, A. (2015). Model Kavramı, (Çev. Alp Tümertekin), İstanbul: İthaki Yayınları.

Bagnasco, O. (2011). “Cemaat”, Sosyolojik Düşünce Sözlüğü, Ed:Raymond Boudon, Massimo Borlandi,

Mohamed Cherkaui, Bernard Valade, İstanbul: İletişim Yayınları.

Bauman, Z. ve Keith Tester (2017). Zygmunt Bauman ile Söyleşiler, (Çev. Mesut Hazır), Ankara: Heretik Yayınları.

Bauman, Z. (2011). Yaşam Sanatı, (Çev. Akın Sarı), İstanbul: Versus Kitap Yayınlar1.

Bauman, Z. (2000). Postmodernlik ve Hoşnutsuzluklarl, (Çev. İsmail Türkmen), İstanbul: Ayrıntı Yayınları.

Bauman, Z. (2017). Cemaatler: Güvenli Olmayan Bir dünyada Güvenlik Arayışı, (Çev. Nurdan Soysal). İstanbul: Say Yayınları. 
Bircan, H. H. (2018). Doğu Batı Arasında Ahlak: Aliya İzetbegoviç Düşüncesinde Insan ve Etik, Konya: Çizgi Kitabevi.

Bozarslan, H. (2016). Lüks ve Şiddet İbn Haldun'da Tahakküm ve Şiddet, (Çev. Melike Işık Durmaz), İstanbul: İletişim Yayınları.

Comte, A. (1986). Pozitivizm Ilmihali, (Çev. Peyami Erman), İstanbul: Milli Eğitim Basımevi.

Comte, A. (2000). Positive Philosophy, (Trans. Harriet Martineau), Batoche Books, Kitchener.

Çaha, Ö., Aktay, Y., Kentel, F. ve Yelken, R. (2011). “Türk Toplumunda Cemaat Algısı Araştırması”, ANDY-AR Sosyal Araştırmalar Merkezi, İstanbul.

Çiğdem, A. (2006). Toplum: Kavram ve Gerçeklik, İstanbul: İletişim Yayınları.

Davutoğlu, A. (2018). Alternatif Paradigmalar: Islam ve Batı Dünya Görüşlerinin Siyaset Teorisine Etkisi, (Çev. Cüneyt Kaya), İstanbul: Küre Yayınları.

Dawson C. (2003). Ilerleme ve Din, (Çev. Yusuf Kaplan, Aylin Doğan), İstanbul: Açılım Kitap Yayınları.

Demir, Ö. Sosyal Bilimler Sözlüğ̈̈, http://omerdemir.net/sosyal-bilimler-sozlugu/ e.t. 2017.

Delanty, G. (2015). Bir Kavramın Anatomisi: Topluluk, (Çev. F. Bilge Atay), İstanbul: Everest Yayınları.

Dilthey, W. (1999). Hermeneutik ve Tin Bilimleri, (Çev. Doğan Özlem). İstanbul: Paradigma Yayınları.

Durali, T. (2000). Çă̆daş Küresel MedeniyetAnlamı/Gelişimi/Konumu-, İstanbul: Dergâh Yayınları.

Durkheim, E. (2009). Dini Hayatın İlk Şekilleri, (Çev. İzzet Er), Ankara: Diyanet Vakfi Yayınları.

Görgün T. (2006). “İbn Haldûn’un Toplum Metafiziğinin Güncelliği ve Günümüzde Toplum Araştırmaları Açısından Önemi”, İslâm Araştırmaları Dergisi, Sayı 16, (169-203).

Giddens, A. (2016). Kapitalizm ve Modern Sosyal Teori, (Çev. Ümit Tatlıcan), İstanbul: İletişim Yayınları.

Günerigök, M. (2018). Risk Toplumu ve Din: Yeni Bir Sosyolojiye Doğru, Ankara: Maarif Yayınları.

Hamilton, P. (2013). “Editörün Önsözü”, Toplum, (Çev. Batuhan Bekmen), İstanbul: Habitus Yayıncılık.

Hobbes, T. (2012). Levithan, (Çev. Semih Lim), İstanbul: YKY Yayınları.

İbn Haldun, (2011). Mukkadime-1, (Çev. Suleyman Uludağ), İstanbul: Dergah Yayınları.

Macler, R. M. ve Charles, H. Page (1969). Cemiyet, (Çev. Amiran Kurtkan), İstanbul: Milli Eğitim Basımevi.
Nisbet, R. (2013). Sosyolojik Düşünce Geleneği, (Çev. Yusuf Kaplan), İstanbul: Paradigma Yayıncilik.

Peter, L. B. ve Thomas Luckmann (2008). Gerçekliğin Sosyal Inşası, (Çev. Vefa Saygın Öğütle), İstanbul: Paradigma Yayınları.

Rousseau, J. J. (2016). Toplumsal Sözleşme ve Siyasal Hukukun Prensipleri, (Çev. Cenap Karakaya), İstanbul: İletişim Yayınları.

Swedberg, R. (2005). The Max Weber Dictionary: Key Words and Concepts, Stanford University Press, Stanford, California.

Swingewood, A. (1998). Sosyolojik Düşüncenin Klssa Tarihi, (Çev. Osman Akınhay), Ankara: Bilim ve Sanat Yayınları.

Tanpınar, A. H. (2018). On Dokuzuncu Asır Türk Edebiyatı Tarihi, Yay. Haz. Abdullah Uçman, İstanbul: Dergah Yayınları.

Tiryakiyan, E. A. "Emile Durkheim”, (Çev. Ceylan Tokluoğlu), Sosyolojik Çözümlemenin Tarihi-1, Ed. Tom Bottomore, T. ve Robert Nisbet (2006). Sosyolojik Çözümlemenin Tarihi, Türkçe Yay. Haz. Mete Tuncay, Aydın Uğur, İstanbul: Kırmızı Yayınları, s.275-343.

Tonnies, F. (2001). Community and Civil Society, Ed. Jose Haris, Trans: Jose Harris and Margaret Hollis, Cambridge: Cambridge Üniversity Press.

Tonnies, F. (2019). Cemaat ve Cemiyet, (Çev. Emre Güler), İstanbul: Vakıfbank Kültür Yayınları.

Turner H. J., Beeghley, L., ve Powers H. C. (2010). Sosyolojik Teorinin Oluşumu, (Çev. Ümit Tatlıcan), Bursa: Sentez Yayınları.

Uzunpostalc1 M. (1993). "Cemaat”, Diyanet İslam Ansiklopedisi, https://islamansiklopedisi.org.tr/, e.t. 2019.

Vandenberghe, F. (2016): Alman Sosyolojisinin Felsefi Tarihi, (Çev. Vefa Saygın Öğütle), İstanbul: Ayrıntı Yayınları.

Yelken, R. (1999). Cemaatin Dönüşümü: Geç Modern Dönemde Cemaat Sosyolojisi, Ankara: Vadi Yayınları.

Yelken, R. (2012). "Cemaatin Yeni Evi: Kent-Metropol”, Kent Sosyolojisi, Ed. Köksal Alver, Ankara: Hece Yayınları, s.257-273.

Wagner, L. (2019). “Cemaat: Büyük Bir Meseleye Kuramsal Bir Yaklaşım”, (Çev. M. Kaan Erdoğan), www.sosyalbilimler.org,e.t. 2019.

Weber, M. (2014). Protestan Ahlakl ve Kapitalizmin Ruhu, (Çev. Mehmet Ökten), İstanbul: Tutku Yayınları.

Williams, R. (2016). Anahtar Sözcükler, (Çev. Savaş Kılıç). İstanbul: İletişim Yayınlar1. 
